Article

\title{
Addressing Younger Workers' Needs: The Promoting U through Safety and Health (PUSH) Trial Outcomes
}

\author{
Diane S. Rohlman ${ }^{1,2}$, Megan Parish ${ }^{1}$, Diane L. Elliot ${ }^{3, *}$, Ginger Hanson ${ }^{4}$ and Nancy Perrin ${ }^{4}$ \\ 1 Oregon Institute of Occupational Health Sciences, Oregon Health \& Science University, \\ Portland, OR 97239, USA; diane-rohlman@uiowa.edu (D.S.R.); parish@ohsu.edu (M.P.) \\ 2 Occupational and Environmental Health, University of Iowa, Iowa City, IA 52242, USA \\ 3 Health Promotion \& Sports Medicine, Oregon Health \& Science University, Portland, OR 97239, USA \\ 4 Center for Health Research, Kaiser Permanente, Portland, OR 97227, USA; \\ Ginger.C.Hanson@kpchr.org (G.H.); Nancy.Perrin@kpchr.org (N.P.) \\ * Correspondence: elliotd@ohsu.edu; Tel.: +1-503-494-6554
}

Academic Editors: Peter A. Leggat and Derek R. Smith

Received: 31 May 2016; Accepted: 5 August 2016; Published: 10 August 2016

\begin{abstract}
Most younger workers, less than 25 years old, receive no training in worker safety. We report the feasibility and outcomes of a randomized controlled trial of an electronically delivered safety and health curriculum for younger workers entitled, PUSH (Promoting U through Safety and Health). All younger workers (14-24 years old) hired for summer work at a large parks and recreation organization were invited to participate in an evaluation of an online training and randomized into an intervention or control condition. Baseline and end-of-summer online instruments assessed acceptability, knowledge, and self-reported attitudes and behaviors. One-hundred and forty participants (mean age 17.9 years) completed the study. The innovative training was feasible and acceptable to participants and the organization. Durable increases in safety and health knowledge were achieved by intervention workers ( $p<0.001$, effect size (Cohen's d) 0.4 ). However, self-reported safety and health attitudes did not improve with this one-time training. These results indicate the potential utility of online training for younger workers and underscore the limitations of a single training interaction to change behaviors. Interventions may need to be delivered over a longer period of time and/or include environmental components to effectively alter behavior.
\end{abstract}

Keywords: young worker; eLearning; occupational; health protection; health promotion

\section{Introduction}

Approximately half of the United States' 16 to 24-year-olds are employed, and that percentage increases by 10 percent during the summer months [1]. Younger workers experience twice the rate of occupational injuries as older workers [2]. Their heightened injury rate is influenced by many factors, including lack of job experience, not recognizing workplace hazards, and limited abilities to communicate effectively with supervisors [2-6]. In addition to work-related safety issues, developmental and lifestyle factors among this age group, such as binge alcohol use [7], balancing school and work demands [8], and sleep deficiency [9], may increase risks of an occupational injury.

Total Worker Health ${ }^{\circledR}$ is a strategy that expands protection from work-related safety and health hazards to incorporate the promotion of health and wellbeing. Increasing evidence suggests that such a strategy may result in more efficient and effective achievement of both objectives $[10,11]$. In addition to their higher injury risk, an integrated approach may have unique benefits among younger workers. For example, adolescence is a time when healthy habits often decline, while harmful actions increase [12], and lifelong behavioral trajectories are initiated [13-16]. Thus, an approach 
addressing both occupational risk and more general lifestyle factors can potentially benefit these emerging adults throughout their lifetime.

Although addressing Total Worker Health ${ }^{\circledR}$ among younger workers may have advantages, achieving this objective is a challenge. Despite employers being required to provide basic safety training for new employees, survey findings indicate that younger workers often received little or no training related to safety in the workplace [17]. A 2013 assessment found approximately one-third of younger workers reported no prior safety training [3], comparable to findings from almost a decade earlier [18].

Recognizing the needs of younger workers, the National Institute for Safety and Health (NIOSH) developed the Youth@Work: Talking Safety curriculum (www.cdc.gov/niosh/talkingsafety/). This six-part, 45-min-per-session teacher-led, classroom-based program is available on the NIOSH website. However, despite customized state-by-state resources, it has realized only limited reach and must compete against an already-overloaded high school curriculum [19].

Rather than a classroom-based curriculum, online technology offers a means to address the challenge of reaching younger workers. Almost all routinely interact online, most have smartphones, and more than three-quarters frequent social networking sites [20]. Adolescents and younger adults perceive the internet as a primary source for health-related information and prefer technology-enhanced educational programs [21]. Properly-designed online educational formats can be as effective as classroom programs for learning new material [22].

Promoting U through Safety and Health (PUSH) is a Total Worker Health ${ }^{\circledR}$ intervention for younger workers, developed through the Oregon Healthy Workforce Center, a NIOSH Total Worker Health $^{\circledR}$ Center of Excellence. PUSH combines content from the Youth@Work: Talking Safety curriculum and two evidence-based adolescent health promotion curricula [23,24]. Content was modified and formatted for a computer-based instruction platform that has been effective in delivering occupational content for diverse worker groups [25-27]. The goal of the current study was to evaluate PUSH training feasibility, acceptability, and efficacy in a randomized, controlled trial among younger workers.

\section{Methods}

\subsection{Study Population}

All workers between the ages of 14 and 24 years old hired for summer employment by an urban parks and recreation bureau were eligible to participate. Most would work as lifeguards, swim instructors, or community center staff. When hired, all workers receive a basic safety orientation and are certified in CPR and first aid as a condition of their employment. Information about the study was presented at worker orientation during the summer of 2013; at this time, parental consent letters were also distributed to minors. Interested individuals provided their email address to research staff, and those potential participants were sent instructions for setting up user accounts on the study's administrative website. The website allowed researchers to record consent, randomize participants, track their progress throughout the study, collect survey responses, link participant data across time points, and send individual and group emails (invitations, reminders, confirmations).

At the start of summer employment, those enrolled were sent a link to a confidential online survey. Following survey completion, an automated application on the study website used a random number algorithm to assign individual participants to the intervention or control condition and link them to the respective online training. At the end of their summer employment, six to eight weeks later, participants were sent a link to a follow-up survey also hosted on the administrative website. Participants were emailed a $\$ 15$ gift card upon completion of the training and a $\$ 30$ gift card after finishing the follow-up survey. Figure 1 shows the participation, randomization, and follow-up numbers. 


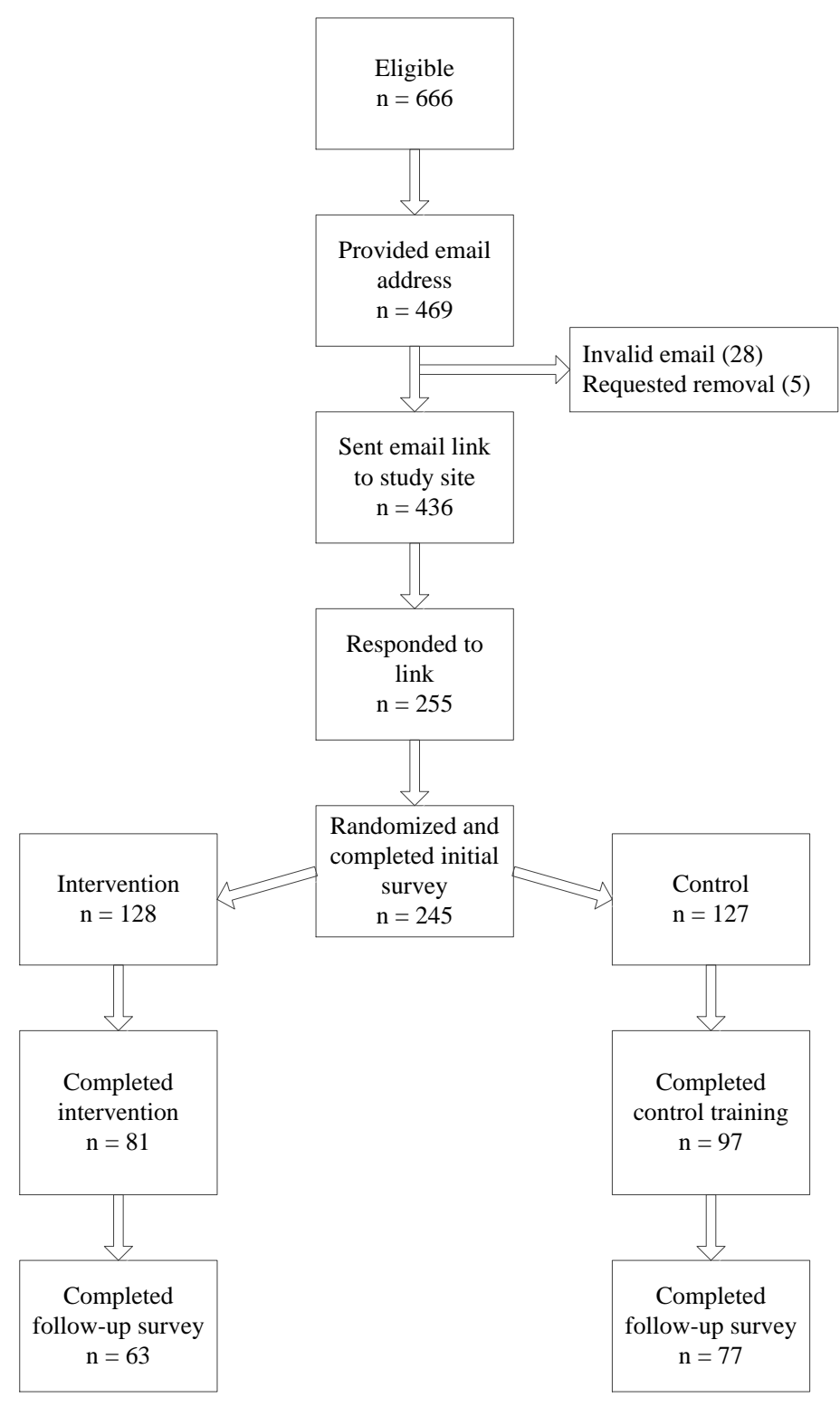

Figure 1. Participant recruitment and retention (data from those completing the intervention and control training were included in the analyses $(n=178))$.

Following orientation and study enrollment, employees were assigned to one job location, for example a neighborhood pool or community center. Accordingly, a given worksite had both intervention and control participants. Work supervisors were not aware of individuals' group assignment. The Oregon Health and Science University Institutional Review Board approved all study materials and procedures.

\subsection{Survey Instrument}

At entry, participants provided demographic information, along with answering knowledge, attitude, and behavior items relating to occupational safety and lifestyle behaviors. The twenty-nine knowledge questions (Table 1) were content covered in the online training (safety, nutrition, physical activity, sleep, substance use, and communication skills), plus five additional items not included in the training. These multiple choice and true/false knowledge items were scored as either correct or incorrect. Participants' responses were reduced to a percentage correct for the PUSH and non-PUSH items. 
Table 1. Survey knowledge items and percentage correct at pre-test.

\begin{tabular}{|c|c|}
\hline Knowledge Items & Pre-Test Percentage Correct \\
\hline \multicolumn{2}{|l|}{ PUSH Training Safety and Lifestyle Items } \\
\hline Best way to tell a coworker to stop horseplay & 68.5 \\
\hline Which is a safety hazard & 97.8 \\
\hline What to say if employer asks you to do something potentially hazardous & 89.3 \\
\hline Which is not a biologic hazard & 80.9 \\
\hline Best way to control a hazard & 49.4 \\
\hline How to respond to being asked to work on new equipment without training & 57.3 \\
\hline Best way to minimize effects of an emergency & 90.5 \\
\hline When to wear appropriate personal protective equipment & 88.8 \\
\hline How to respond to agitated customer & 94.4 \\
\hline How to ask about your safety when asked to do a new task & 83.7 \\
\hline How to talk with employer about safety hazard & 83.2 \\
\hline What statement is not true about sexual harassment & 79.8 \\
\hline Number of recommended servings of fruits and vegetables each day & 47.2 \\
\hline Which is least healthy snack & 53.7 \\
\hline How much exercise is recommended each day by the CDC & 29.8 \\
\hline Which nutrient builds and repairs your body & 93.8 \\
\hline Orange juice is what type of carbohydrate & 57.9 \\
\hline You can be sleep deprived and not know it (T/F) & 97.2 \\
\hline $\begin{array}{l}\text { Chicken and fish are always the healthiest of the meat options at a fast food } \\
\text { restaurant }(\mathrm{T} / \mathrm{F})\end{array}$ & 55.6 \\
\hline $\begin{array}{l}\text { Alcohol and drug use by workers is related to more than half of all } \\
\text { workplace injuries and fatalities }(\mathrm{T} / \mathrm{F})\end{array}$ & 76.4 \\
\hline $\begin{array}{l}\text { If you are } 16 \text { years old and have a valid driver's license you are allowed to } \\
\text { drive a car on public streets as part of your job }(\mathrm{T} / \mathrm{F})\end{array}$ & 39.9 \\
\hline $\begin{array}{l}\text { Practicing emergency protocols is an important part of preparing for } \\
\text { emergencies }(\mathrm{T} / \mathrm{F})\end{array}$ & 98.3 \\
\hline $\begin{array}{l}\text { The law says your employer is responsible for providing you with a safe } \\
\text { and healthy workplace }(\mathrm{T} / \mathrm{F})\end{array}$ & 93.3 \\
\hline $\begin{array}{l}\text { If you're injured on the job, your employer must pay for your } \\
\text { medical care }(\mathrm{T} / \mathrm{F})\end{array}$ & 62.9 \\
\hline \multicolumn{2}{|l|}{ Non-PUSH Content Items } \\
\hline Which one is not an aspect of positive thinking & 86.0 \\
\hline What is the first step to positive thinking & 70.2 \\
\hline Skin cancer can be cured if it is caught early enough $(\mathrm{T} / \mathrm{F})$ & 85.4 \\
\hline $\begin{array}{l}\text { UV radiation is stronger around water, because the water reflects the } \\
\text { sunlight }(T / F)\end{array}$ & 91.0 \\
\hline $\begin{array}{l}\text { Self-talk is the stream of unspoken thoughts in our head. Self-talk can be } \\
\text { either positive or negative }(\mathrm{T} / \mathrm{F})\end{array}$ & 96.6 \\
\hline
\end{tabular}

The attitude and behavior items related to safety and health made up four reliable constructs, which are shown in Table 2. For these items, participants responded using a seven-point agreement scale from strongly disagree to strongly agree. Thus, higher scores indicate more favorable responses. Construct scores were computed by taking the mean of the relevant items. At follow-up, intervention participants also were queried about reactions to the training and self-reported behavior change. The survey took $20 \mathrm{~min}$, with the intervention and control training lasted approximately $1 \mathrm{~h}$. 
Table 2. Behavior and attitude constructs.

\begin{tabular}{|c|c|c|}
\hline Construct & Items in the Construct & Alpha Reliability \\
\hline $\begin{array}{l}\text { Health } \\
\text { Behavior }\end{array}$ & $\begin{array}{l}\text { I bring healthy snacks to work } \\
\text { I eat breakfast everyday } \\
\text { I stick to healthy food options when I eat out } \\
\text { I get at least } 8 \text { h of sleep a night } \\
\text { I sometimes drive when I am drowsy or tired * } \\
\text { I make time for exercise each day } \\
\text { I avoid engaging in behaviors before work that could jeopardize my } \\
\text { attention and judgment }\end{array}$ & 0.59 \\
\hline $\begin{array}{c}\text { Safety } \\
\text { Behavior }\end{array}$ & $\begin{array}{l}\text { I have looked at the emergency preparedness plans in my workplace } \\
\text { I read the information about a chemical before I use it } \\
\text { I ask for help or training before trying a new task at work } \\
\text { I communicate professionally at work }\end{array}$ & 0.73 \\
\hline \multirow[b]{2}{*}{$\begin{array}{c}\text { Health } \\
\text { Attitudes }\end{array}$} & $\begin{array}{l}\text { Hydration is important to staying focused and alert on the job } \\
\text { I think eating breakfast everyday is important } \\
\text { Proper nutrition is important to workplace safety } \\
\text { Getting enough sleep at night is important to me } \\
\text { I know how to deal with my emotions in a healthy way }\end{array}$ & \multirow[b]{2}{*}{0.76} \\
\hline & $\begin{array}{l}\text { I think on the job injuries are a serious and common problem } \\
\text { An injury I receive on the job could potentially have a long-lasting } \\
\text { negative impact on my life } \\
\text { I know how to protect myself from injuries in my workplace } \\
\text { I know how to identify hazards in my workplace } \\
\text { I have the ability to improve the safety of my workplace } \\
\text { I can make a difference in the safety of my workplace } \\
\text { I am confident I would respond appropriately }\end{array}$ & \\
\hline
\end{tabular}

* Reverse coded.

\subsection{PUSH Training}

The PUSH training included topics derived from the NIOSH Youth@Work: Talking Safety curriculum, health promotion (nutrition, hydration, sleep, and substance abuse), and effective communication in the workplace. The online format used the cTrain platform [28], which is a format for self-paced computer-based training. An icon-based navigation system directed participants through a series of content screens, punctuated by brief videos. At intervals, multiple choice question screens reinforced content and required correct answers to progress through the training. Training was completed in approximately $60 \mathrm{~min}$, and an example of a training screen is shown in Figure 2.

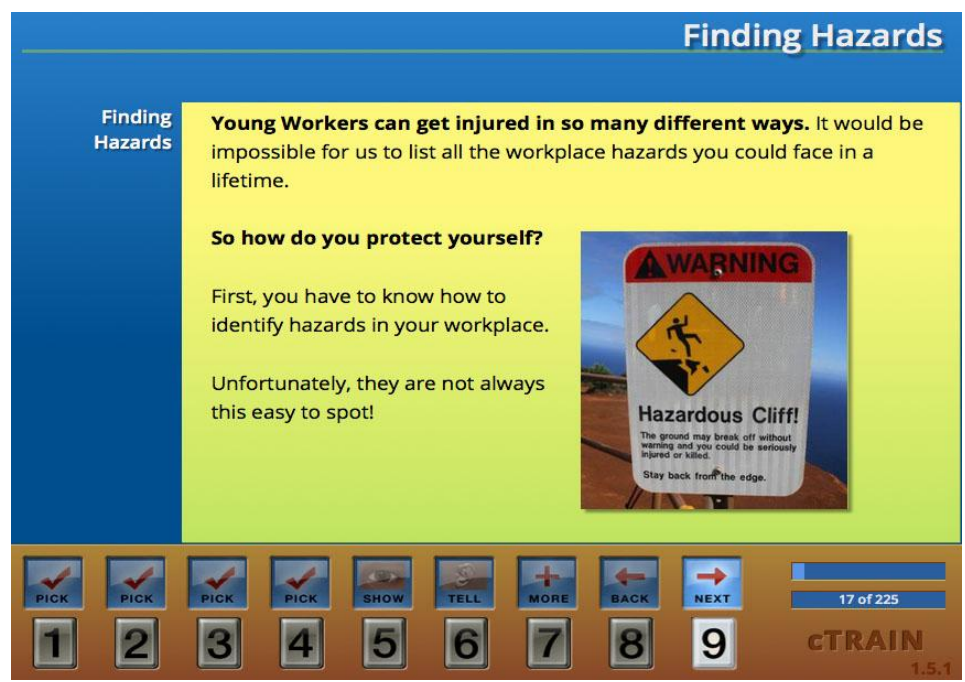

Figure 2. Example of the PUSH screen. 


\subsection{Control Condition}

The control participants received a 50 min training using an established program on sun safety [29] and content about the benefits of positive thinking. The intervention participants did not receive this training.

\subsection{Statistical Analyses}

Data was analyzed with SPSS (IBM SPSS Statistics for Windows, Version 22.0, IBM Corp, Armonk, NY, USA). Chi-square and t-tests were used to examine differences between the groups at baseline. Generalized estimating equations (GEE) models were used to test differences in change from baseline to follow-up between the training and control groups' attitudes and behaviors. GEE handles missing data by using the all available pairs method in which all non-missing pairs of data are used in estimating the working correlation parameters. Repeated waves of data are structured into a long dataset allowing for the use of all available data, so that cases are not lost due to missing data. Time, group, and time $\times$ group interaction were included in the model. Effects sizes were computed using the adjusted means and standard errors from the GEE model. Specifically, we computed the Cohen's d as the difference in scores divided by the pooled baseline standard deviation.

\section{Results}

\subsection{Participant Characteristics}

Intervention and control participants' baseline findings are presented in Table 3. Group demographics and body weights (body mass index (BMI) and percentages in BMI subgroups) were comparable at baseline, other than significantly more females being in the control condition. Gender was included as a control variable in the longitudinal analyses to statistically control for this baseline difference.

Table 3. Baseline descriptive information (percentages and means (standard errors)).

\begin{tabular}{ccc}
\hline & Control $(\boldsymbol{n = 9 7 )}$ & PUSH Intervention $(\boldsymbol{n}=\mathbf{8 1})$ \\
\hline & Demographics \\
\hline Age (years) Age (years) & $18.2(0.2)$ & $17.7(0.2)$ \\
Percent Female Percent Female & $60.8 \%$ & $45.7 \%$ * \\
Percent White Percent White & $77.1 \%$ & $76.5 \%$ \\
Graduated High School & $56.7 \%$ & $45.7 \%$ \\
First Job & $75.3 \%$ & $81.5 \%$ \\
\hline & Anthropometrics \\
\hline BMI (self-reported height and weight) & $23.2(4.1)$ & $22.7(4.4)$ \\
Underweight Underweight & $2.1 \%$ & $2.5 \%$ \\
Normal Normal & $77.9 \%$ & $77.5 \%$ \\
Overweight Overweight & $12.6 \%$ & $7.5 \%$ \\
Obese Obese & $7.4 \%$ & $4.9(0.1)$ \\
Attitudes and Behavior Constructs (1 to 7 scale, higher is healthier) \\
\hline Health Behavior & $4.9(0.1)$ & $5.7(0.1)$ \\
Safety Behavior & $5.5(0.1)$ & $6.0(0.1)$ \\
Health Attitude & $5.8(0.1)$ & $5.6(0.2)$ \\
Safety Attitude & $5.4(0.1)$ & \\
\hline & $7.4(0.1)$ & $19.8 \%$ \\
\hline Average Hours Sleep per Night & $26.8 \%$ & \\
Drink Until Drunk Past Month & &
\end{tabular}


Table 3. Cont.

\begin{tabular}{ccc}
\hline & Control $(n=97)$ & PUSH Intervention $(n=81)$ \\
\hline Sugary Snacks & Diet $\ddagger$ & \\
Drinks with Added Sugar & $4.2(0.2)$ & $3.3(0.2)^{*}$ \\
Fast Food & $3.6(0.2)$ & $2.8(0.2)^{*}$ \\
Meals from Home Fast Food & $1.5(0.1)$ & $1.3(0.1)$ \\
Fruits and Vegetables & $6.1(0.2)$ & $5.9(0.2)$ \\
\hline At least 90 min each week & $6.6(0.2)$ & $6.3(0.2)$ \\
\hline
\end{tabular}

* Significant differences between control and intervention groups $(p<0.05) ;{ }^{\ddagger}$ Diet items were answered using a frequency continuum from 0 , never; $1<$ once a month; 3 , once or twice a week; 6 , once a day; to 8 , for three or four times a day.

\subsection{Feasibility and Acceptability}

When queried at the end of their summer employment, the majority of intervention participants enjoyed the training (59\%), reported that they learned new information (95\%), self-reported that they had changed behaviors as a result of the training $(63 \%)$, and would recommend it to others $(67 \%)$. The parks and recreation department also found it easy to administer and requested making the training mandatory for all new employees the following year.

\subsection{Program Effects}

The pretest knowledge of participants was high (Table 1), and there were no differences between groups at baseline. Using GEE analyses to examine differences over time, while controlling for gender, the intervention participants had a significant increase in the number of correct PUSH knowledge items at the summer's conclusion follow-up assessment. The adjusted means, standard error, effect sizes and $p$-value for each training $\times$ time interaction are presented in Table 4 . The greater increase in knowledge in the intervention group was a small-moderate effect size $(d=0.40)$. Follow-up GEE analyses separating the PUSH knowledge items into three subscales: (1) communication, (2) health, and (3) safety, revealing that only the difference in change between intervention and control groups on safety knowledge was significant. Changes in the attitude and behavioral constructs also are shown in Table 4. Mean values decreased among intervention participants, although still remaining in the favorable range on the Likert agreement scale.

Table 4. Scores for the knowledge plus safety and health behavior and attitude constructs (estimated mean (SEM)).

\begin{tabular}{|c|c|c|c|c|c|c|}
\hline & \multicolumn{2}{|c|}{$\begin{array}{c}\text { Control } \\
n=97\end{array}$} & \multicolumn{2}{|c|}{$\begin{array}{c}\text { PUSH Intervention } \\
\qquad n=81\end{array}$} & \multirow[t]{2}{*}{$p$ Value } & \multirow[t]{2}{*}{ Cohen's d } \\
\hline & Pre- & Post- & Pre- & Post- & & \\
\hline \multicolumn{7}{|c|}{ Knowledge Items } \\
\hline $\begin{array}{l}\text { PUSH Training Knowledge Items } \\
\text { (number correct) }\end{array}$ & $18.2(0.4)$ & $18.2(0.4)$ & $18.4(0.5)$ & $20.2(0.5)$ & $<0.001$ & 0.4 \\
\hline $\begin{array}{l}\text { Non-PUSH Training Knowledge } \\
\text { Items (number correct) }\end{array}$ & $4.2(0.1)$ & $4.6(0.1)$ & $4.3(0.2)$ & $4.4(0.2)$ & 0.07 & -0.21 \\
\hline \multicolumn{7}{|c|}{ Safety and Health Behavior and Attitude Constructs } \\
\hline Health Behavior & $4.9(0.12)$ & $5.0(0.13)$ & $4.9(0.14)$ & $4.9(0.15)$ & 0.220 & -0.15 \\
\hline Safety Behavior & $5.5(0.15)$ & $5.6(0.15)$ & $5.7(0.17)$ & $5.2(0.18)$ & 0.009 & -0.36 \\
\hline Health Attitude & $5.8(0.13)$ & $5.9(0.13)$ & $6.0(0.15)$ & $5.6(0.16)$ & 0.013 & -0.37 \\
\hline Safety Attitude & $5.4(0.13)$ & $5.6(0.14)$ & $5.6(0.15)$ & $5.4(0.16)$ & 0.015 & -0.37 \\
\hline
\end{tabular}




\section{Discussion}

PUSH is the first implementation of an online Total Worker Health ${ }^{\circledR}$ training for younger workers. It integrated both occupational and non-occupational risk factors to more comprehensively address issues, and it used a format relevant for these technologically adept new younger employees. The training was easily administered and rated positively by participants. Results indicated that there were increases in knowledge among those completing the PUSH curriculum, and those favorable changes persisted during their summer employment.

PUSH used online training or e-learning, which broadly includes all forms of electronically-supported teaching [30]. A review of more than 20,000 worker education trials challenged the proliferation of employee educational videos and online trainings, noting that passively viewing a video, lecture, or viewing educational screens has limited ability to increase understanding and recall [31]. For example, less than 10 percent of lecture content is durably retained [32]. Those findings are well supported by adult learning theory's emphasis on actively processing material for incorporating new knowledge [33]. However, unlike most trainings the cTrain platform differed in that it required mastery of knowledge items before progressing through the training, which forced participants to process material and facilitated the observed durable retention of PUSH knowledge content throughout the summer. The common wisdom is that knowledge-based programs have limited impact on behaviors, and longitudinal programs are needed to change actions [34-37]. We recognized that altering behavior with PUSH training would be a challenge, given its one-time nature and the constraints of having no follow-up worksite components to avoid diffusion of the intervention to control participants working at the same pool or other specific worksite. The findings underscore the limitations of both one-time training activities and the importance of including multiple levels of evaluation to assess the efficacy of worksite trainings. The American Society for Training and Development found that the majority of organizations only assessed training effectiveness with participant reactions [38]. Using that metric PUSH was rated positively by the majority of participants. A minority of employee trainings ask about whether behaviors were changed, as the assessments often immediately follow the video or online training. Using that "did you change" index, the majority of PUSH participants also reported changing their behaviors due to the training.

A more accurate measure of behavior is the pre-post-design, which is rare in most worker training programs. Using this rigorous index, $\mathrm{PUSH}$ did not find positive changes in attitudes or behaviors. Again, in this proof-of-concept study, without longitudinal and environmental components, behavioral changes were not expected. However, behaviors and attitudes appeared to decline, although still remaining at comparably favorable levels. What may explain the paradoxical findings relating to a decrease in attitudes and behaviors? A basic assumption of the pre- to post-test design is that the underlying metric used remains the same for both time points. However, as pre-test participants may have only a partial understanding of the items to be measured, at the end of the experience, their calibration may have changed. This response bias shift has been observed in other settings and poses a threat to the instrument's internal validity $[39,40]$. As was seen here, participants tend to reduce their self-ratings after an intervention [38]. Rather than a negative finding, the decrease in values may represent heightened awareness of safety and health by PUSH intervention participants. This interpretation may be further supported by the participants' generally positive reactions to the PUSH training, which demonstrated that youth enjoyed the training and self-reported that their knowledge and behavior had changed as a result of the training.

Our study has limitations. It was conducted in one geographic location, and participants, although representative of the community, were primarily white, well-educated and English speaking. Furthermore, many of the youth were employed as lifeguards, which is a safety-conscious occupation.

While knowledge may be permissive, it seldom alters behavior. Our findings emphasize the need for including reinforcing behavioral change with explicit messaging and worksite cues to safe and healthy actions. Enhancing PUSH with a follow-up system of text and social media messaging could reinforce and normalize safe and healthy actions. This sort of ongoing contact has been a component 
of online programs to alter younger adults' diets and disease management behaviors [41-43] and could supplement the PUSH curriculum. In addition, including an environmental component, such as PUSH training-related worksite posters and supervisor reinforcement, would be predicted to reinforce attitude and behavior change [44].

\section{Conclusions}

Web-based training is a feasible and acceptable format for younger workers. As a stand-alone one-time interaction it produced sustained knowledge gains. Reinforcing content and adding environmental components may allow extending positive outcomes to attitudes and behaviors. The study also demonstrates the utility of pre- to post- assessments, rather than just self-reported change and reactions, when evaluating worker trainings.

Acknowledgments: We thank Portland Parks and Recreation for their enthusiastic support of this project, particularly Barbara Aguon, Larissa Doty, and Nancy Roth.

Author Contributions: Diane S. Rohlman, conceived the design of the work and obtained funding for the project. She supervised and participated in the final design, instrument and intervention development and data collection. She supervised the analysis and preparation of findings. Megan Parish, was the project manager and participated in all aspects of conducting the trial and interpretation of findings. Diane L. Elliot, was a co-investigator for the entire project and worked with Rohlman and Parish in the study design, collection of data and analysis. Ginger Hanson and Nancy Perrin, were involved in study design and primarily responsible for data analysis and preparation of findings. Each of the authors have participating in drafting this manuscript and critically reviewing its intellectual content. They have approved the final manuscript and agree to be accountable for all aspects of the work.

Conflicts of Interest: Diane S. Rohlman has a significant financial interest in Northwest Education Training and Assessment, LLC, a company that may have a commercial interest in the results of this research and technology. This potential conflict of interest was reviewed and a management plan approved by the University of Iowa and the OHSU Conflict of Interest in Research Committee. ATLAS and ATHENA are programs on the Substance Abuse and Mental Health Services Administration's National Registry of Evidence-based Programs and Practices, and they are distributed through the Center for Health Promotion Research at OHSU. OHSU and Diane L. Elliot have a financial interest from the sale of those technologies. The potential conflict of interest has been reviewed and managed by the OHSU Conflict of Interest and Research Committee. For the remaining authors no conflicts are declared. No author received and honorarium or specific funding to produce this manuscript.

\section{References}

1. Bureau of Labor Statistics. Employment and Unemployment among Youth-Summer 2014. Available online: http:/ / www.bls.gov/news.release/archives/youth_08132014.pdf (accessed on 28 November 2015).

2. Estes, C.R.; Jackson, L.L.; Castillo, D.N. Occupational injuries and deaths among younger workers-United States, 1998-2007. Morb. Mortal. Wkly. Rep. 2010, 59, 449-455.

3. Frone, M.R. Predictors of work injuries among employed adolescents. J. Appl. Psychol. 1998, 83, 565-576. [CrossRef] [PubMed]

4. Rohlman, D.S.; Parish, M.; Elliot, D.L.; Montgomery, D.; Hanson, G. Characterizing the needs of a young working population: Making the case for total worker health in an emerging workforce. J. Occup. Environ. Med. 2013, 55, 69-72. [CrossRef] [PubMed]

5. Simoyi, P.; Frederick, L.; Niezen, C. Teenagers' experience with occupational health and safety issues in West Virginia. Hum. Ecol. Risk Assess. 2001, 4, 1405-1415. [CrossRef]

6. Westaby, J.D.; Lowe, J.D. Risk-taking orientation and injury among youth workers: Examining social influences of supervisors, coworkers and parents. J. Appl. Psychol. 2005, 90, 1027-1035. [CrossRef] [PubMed]

7. Parish, M.; Rohlman, D.S.; Elliot, D.L.; Lasarev, M. Factors associated with occupational injuries in seasonal young workers. Occup. Med. 2015. [CrossRef] [PubMed]

8. Teixeira, L.R.; Fischer, F.M.; Nagai, R.; Turte, S.L. Sleep patterns of day-working, evening high-schooled adolescents of San Paulo, Brazil. Chronobiol. Int. 2004, 21, 239-252. [CrossRef] [PubMed]

9. Wolfson, A.R.; Carskadon, M.A. Sleep schedules and daytime functioning in adolescents. Child Dev. 1998, 69, 875-887. [CrossRef] [PubMed]

10. Sauter, S.L. Integrative approaches to safeguarding the health and safety of workers. Ind. Health 2013, 51, 559-561. [CrossRef] [PubMed] 
11. Merchant, J.A.; Hall, J.L.; Howard, J. Total Worker Health ${ }^{\mathrm{TM}}$ symposium. J. Occup. Environ. Med. 2013, 55, S1-S7. [PubMed]

12. Holman, D.M.; White, M.C. Dietary behaviors related to cancer prevention among pre-adolescents and adolescents: The gap between recommendations and reality. Nutr. J. 2011. [CrossRef] [PubMed]

13. Gordon-Larsen, P.; Nelson, M.C.; Popkin, B.M. Longitudinal physical activity and sedentary behavior trends: Adolescence to adulthood. Am. J. Prev. Med. 2004, 27, 277-283. [CrossRef] [PubMed]

14. Graham, D.J.; Sirard, J.R.; Neumark-Sztainer, D. Adolescents' attitudes toward sports, exercise, and fitness predict physical activity 5 and 10 years later. Prev. Med. 2011, 52, 130-132. [CrossRef] [PubMed]

15. Neumark-Sztainer, D.; Wall, M.; Story, M.; Standish, A.R. Dieting and unhealthy weight control behaviors during adolescence: Associations with 10-year changes in body mass index. J. Adolesc. Health 2012, 50, 80-86. [CrossRef] [PubMed]

16. Hoyt, L.T.; Chase-Lansdale, P.L.; McDade, T.W.; Adam, E.K. Positive youth, healthy adults: Does positive well-being in adolescence predict better perceived health and fewer risky health behaviors in young adulthood? J. Adolesc. Health 2012, 50, 66-73. [CrossRef] [PubMed]

17. U.S. Department of Labor. Training Requirements in Osha Standards and Training Guidelines. Available online: https:/ / www.osha.gov/Publications/osha2254.pdf (accessed on 28 November 2015).

18. Runyan, C.W.; Schulman, M.; Dal Santo, J.; Bowling, J.M.; Agans, R.; Ta, M. Work-related hazards and workplace safety of U.S. adolescents working in the retail and service sectors. Pediatrics 2007, 119, 526-534. [CrossRef] [PubMed]

19. National Counsel for Curriculum and Assessment. Curriculum Overload in Primary Schools. Available online: http://www.ncca.ie/en/Publications/Reports/Curriculum_overload_in_Primary_ Schools_An_overview_of_national_and_international_experiences.pdf (accessed on 29 November 2015).

20. Lenhart, A.; Purcell, K.; Smith, A.; Zickuhr, K. Social media and mobile internet use among teens and young adults. Available online: http:/ /www.pewinternet.org/2010/02/03/social-media-and-young-adults/ (accessed on 28 November 2015).

21. Rideout, V.; Foehr, U.; Roberts, D. Generation M2: Media in the Lives of 8- to 18-Year-Olds; Henry J. Kaiser Family Foundation: Menlo Park, CA, USA, 2010.

22. Sitzmann, T.; Kraiger, K.; Stewart, D.; Wisher, R. The Comparative effectiveness of web-based and classroom instruction: A meta-analysis. Pers. Psychol. 2006, 59, 623-664. [CrossRef]

23. Goldberg, L.; MacKinnon, D.P.; Elliot, D.L.; Moe, E.L.; Clarke, G.; Cheong, J. The adolescents training and learning to avoid steroids program: Preventing drug use and promoting healthy behaviors. Arch. Pediatr. Adolesc. Med. 2000, 154, 332-338. [CrossRef] [PubMed]

24. Elliot, D.L.; Goldberg, L.; Moe, E.L.; DeFrancesco, C.A.; Durham, M.B.; Hix-Small, H. Preventing substance use and disordered eating: Initial outcomes of the ATHENA (athletes targeting healthy exercise and nutrition alternatives) program. Arch. Pediatr. Adolesc. Med. 2004, 158, 1043-1049. [CrossRef] [PubMed]

25. Anger, W.K.; Patterson, L.; Fuchs, M.; Will, L.L.; Rohlman, D.S. Learning and recall of worker protection standard (WPS) training in vineyard workers. J. Agromed. 2009, 14, 336-344. [CrossRef] [PubMed]

26. Glass, N.; Bloom, T.; Perrin, N.; Anger, W.K. A computer-based training intervention for work supervisors to respond to intimate partner violence. Saf. Health Work 2010, 1, 167-174. [CrossRef] [PubMed]

27. Olson, R.; Anger, W.K.; Elliot, D.L.; Wipfli, B.; Gray, M. A new health promotion model for lone workers: Results of the Safety \& Health Involvement for Truckers (SHIFT) pilot study. J. Occup. Environ. Med. 2009, 51, 1233-1246. [PubMed]

28. Anger, W.K.; Rohlman, D.S.; Kirkpatrick, J.; Reed, R.R.; Lundeen, C.A.; Eckerman, D.A. cTrain: A computer-aided training system developed in SuperCard for teaching skills using behavioral education principles. Behav. Res. Methods Instrum. Comput. 2001, 33, 277-281. [CrossRef] [PubMed]

29. Geller, A.; Rutsch, L.; Kenausis, K.; Zhang, Z. Evaluation of the SunWise school program. J. Sch. Nurs. 2003, 19, 93-99. [CrossRef] [PubMed]

30. Horton, W. e-Learning by Design; John Wiley \& Sons, Inc.: San Francisco, CA, USA, 2011.

31. Burke, M.J.; Sarpy, S.A.; Smith-Crowe, K.; Chan-Serafin, S.; Salvador, R.O.; Islam, G. Relative effectiveness of worker safety and health training methods. Am. J. Public Health 2006, 96, 315-324. [CrossRef] [PubMed]

32. Cantor, J.A. Delivering Instruction to Adult Learners, 3rd ed.; Wall \& Emerson, Inc.: Toronto, ON, Canada, 2008.

33. Knowles, M.S.; Holton, E.F., III; Swanson, R.A. The Adult Learner, 8th ed.; Routledge: New York, NY, USA, 2015. 
34. Contento, I.; Balch, G.I.; Bronner, Y.L.; Lytle, L.A.; Maloney, S.K.; Olson, C.M.; Swadener, S.S. The effectiveness of nutrition education and implications for nutrition education policy, programs, and research: A review of research. J. Nutr. Educ. 1995, 27, 277-418.

35. Lorig, K.R.; Holman, H.R. Self-management and education: History, definition, outcomes, and mechanisms. Ann. Behav. Med. 2003, 26, 1-7. [CrossRef] [PubMed]

36. Rothman, A.; Kiuiniemi, M. Treating people with information: an analysis and review of approaches to community risk information. J. Natl. Cancer Inst. Monogr. 1999, 25, 44-57. [CrossRef] [PubMed]

37. U.S. Department of Health \& Human Services. Preventing Drug Use among Children and Adolescents. 2003. Available online: http://drugabuse.gov/pdf/prevention/redbook.pdf (accessed on 29 November 2015).

38. Thompson, C.; Koon, E.; Woodwell, W.H., Jr.; Beauvais, J. Training for the Next Economy: An Astd State of the Industry Report on Trends in Employer-Provided Training in the United States for 2002; American Society for Training and Development: Alexandria, VA, USA, 2002.

39. Moore, D.; Tananis, C.A. Measuring change in a short-term educational program using a retrospective pretest design. Am. J. Educ. 2009, 30, 189-202. [CrossRef]

40. Aiken, L.S.; West, S.G. Invalidity of true experiments self-report pretest biases. Eval. Rev. 1990, 14, 374-390. [CrossRef]

41. Militello, L.K.; Kelly, S.A.; Melnky, B.M. Systematic review of text-messaging interventions to promote healthy behaviors in pediatric and adolescent populations: Implications for clinical practice and research. Worldviews Evid. Based Nur. 2012, 9, 66-77. [CrossRef] [PubMed]

42. Krebs, P.; Prochaska, J.O.; Rossi, J.S. A meta-analysis of computer-tailored interventions for health behavior change. Prev. Med. 2010, 51, 214-221. [CrossRef] [PubMed]

43. Webb, T.L.; Joseph, J.; Yardley, L.; Michie, S. Using the internet to promote health behavior change: A systematic review and meta-analysis of the impact of theoretical basis, use of behavior change techniques, and mode of delivery on efficacy. J. Med. Internet Res. 2010. [CrossRef] [PubMed]

44. Sallis, J.F.; Cervero, R.B.; Ascher, W.; Henderson, K.A.; Kraft, M.K.; Kerr, J. An ecological approach to creating more physically active communities. Annu. Rev. Public Health 2006, 27, 297-322. [CrossRef] [PubMed]

(C) 2016 by the authors; licensee MDPI, Basel, Switzerland. This article is an open access article distributed under the terms and conditions of the Creative Commons Attribution (CC-BY) license (http://creativecommons.org/licenses/by/4.0/). 